\title{
STEROL COMPOSITION FROM INFLORESCENCES OF HIERACIUM PILOSELLA L.
}

\author{
MONIKA GAWROŃSKA-GRZYWACZ, TADEUSZ KRZACZEK \\ Department of Pharmaceutical Botany of the Medical University of Lublin \\ Chodźki 1, 20-093 Lublin, Poland \\ e-mail: tadeusz.krzaczek@am.lublin.pl
}

(Received: May 30, 2005. Accepted: September 28, 2005)

\begin{abstract}
The fraction of sterol acetates from the inflorescences of Hieracium pilosella has been isolated in the typical way from petroleum ether extract. By means of the weight method the total amount of sterols was determined $(0.2659 \%)$. The mixtures of sterol acetates and free sterols were investigated using GC-MS techniques. The

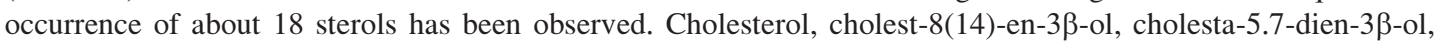
cholest-7-en-3 $\beta$-ol, ergosta-5.24-dien-3 $\beta$-ol, campesterol, stigmasterol, $\beta$-sitosterol, fucosterol, $5 \alpha$-stigmast-7-en$3 \alpha$-ol were identified. The probable structures of lophenol, isofucosterol, $5 \alpha$-stigmasta-7.24-dien-3 $\beta$-ol, lanosta9(11).24-dien-3 $\beta$-ol and 24-ethylidene lophenol were stated on the basis of literature data. The last 4 sterols occur in a vestigial quantity, which made its identification impossible. Sitosterol and cholesterol are remarkably dominating sterols in the fraction.
\end{abstract}

KEY WORDS: Hieracium pilosella, phytosterols, GC-MS.

\section{INTRODUCTION}

Hieracium pilosella L. (Asteraceae) is a common plant widely growing in Poland. It usually occurs on dry meadows, not very fertile pastures, sunny slopes of hills and forms thick pieces (Bown 1999; Broda and Mowszowicz 2000; Mowszowicz J. 1980). Herba Pilosellae is used in folk medicine for its diuretic, adstringent, antiseptic, spasmolytic, antiphlogistic and expectorant activity (Beaux et al. 1999; Bown 1999; Broda and Mowszowicz 2000; Kuźniewski and Augustyn-Puziewicz 1984). Traditionally it was used in treating of cystitis, nephritis and urolithiasis and also cough, whooping cough, asthma and respiratory tract's inflammations and bleedings from (Bown 1999; Broda and Mowszowicz 2000). Externally the extracts from $H$. pilosella were used to bathe septic wounds (Bown 1999; Dombrowicz et al. 1992; Kuźniewski and AugustynPuziewicz 1984). Therapeutically active components of this species are known to a small extent and due to various bioactivities of its extract, they have received considerable attention (Beaux et al. 1999; Broda and Mowszowicz 2000; Dombrowicz et al. 1992; Harborne 1978; Hegnauer 1964, 1989). Some of the therapeutical features of this herb may be attributed to sterol constituents, especially anti-inflammatory activity (Kohlmünzer 1998).
In the subfamily of Cichorioideae, where this species is classified to, the occurrence of phytosterols is quite often. Stigmasterol, $\beta$-sitosterol and more rarely $\alpha$-spinasterol, campesterol and cholesterol appear among these, producing milk juice plants (Hegnauer 1964, 1989; Kohlmünzer 1998). In the previous work the sterols in the roots and herb of Hieracium pilosella were identified and the total amount of them was determined (Krzaczek et al. 2002).

The aim of the study was isolation and analysis of the sterols in the inflorescences from Hieracium pilosella $\mathrm{L}$.

\section{MATERIAL AND METHODS}

\section{Plant material}

The plant material for research were the inflorescences of Hieracium pilosella L. collected in Ćmiłów near Lublin in June 2004. It was dried in normal conditions and adequately fragmented (PPh. V). $1000 \mathrm{~g}$ of the inflorescences were used in the study.

\section{Extraction and isolation}

The material was extracted with petroleum ether (with boiling point $45-60^{\circ} \mathrm{C}$ ) in a Soxhlet apparatus for over 60 hours. The petroleum ether extract of the lipids was evapo- 
rated under vacuum. $67.15 \mathrm{~g}$ of yellow-brown residue-oil was obtained. The oil residue was saponified with $10 \%$ ethanolic KOH solution for 9 hours (Jerzmanowska 1967). The solution was reduced to about half volume under vacuum, diluted with water and extracted with diethyl ether. The etheral phase was washed with water until neutral, dried and evaporated to obtain crude unsaponifiable fraction. Sterols were separated in a typical way by precipitation with digitonine (1\% digitonine solution in $80 \%$ ethanolic, warmed with unsaponifiable fraction for 1 hour in $70^{\circ} \mathrm{C}$ ). The obtained digitonides of sterols were filtered and washed with ethanol and acetylation was performed (acetic acid anhydrous, with anhydrous natrium acetate, $2 \mathrm{~h}$, $100^{\circ} \mathrm{C}$ ) and next sterol acetates crystallized from $50 \%$ ethanol (Jerzmanowska 1967; Strzelecka 1987). The sterols' acetates mixture was investigated by capillary GC and GC-MS. Saponification of this mixture yielded the free sterols which were again identified by GC-MS. The total amount of the sterols was determined by means of the weight method (Jerzmanowska 1967).

\section{Gas chromatography (GC)}

Gas chromatography was carried out using Carlo-Erba Instruments Chromatograph (Italy), equipped with detector FID and injector SSL. The sterols were separated on the capillary column of $0.32 \mathrm{~mm}$ bore and $30 \mathrm{~m}$ length, packed with RTx-1 (0.1 $\mu \mathrm{m}$ size $)$ and operated at $300^{\circ} \mathrm{C}$.

The following optimum conditions of analysis were stated: temp. of analysis 200-330 (15 min isotermic), temp. of injector $320^{\circ} \mathrm{C}$, temp. of detector $310^{\circ} \mathrm{C}$, growth of temperature $6^{\circ} \mathrm{C} / \mathrm{min}$, flow-rate of carrier gas $\left(\mathrm{N}_{2}\right)-1.3 \mathrm{ml} / \mathrm{min}$.

The sterols were identified on the basis of comparison of the retention times of the analyzed compounds with authentic standards.

\section{GC/MS}

GC-MS analysis of sterol mixture was carried out using GC 8000 Fision Instruments (Italy) equipment with detector MD 800, injector SSL and $30 \mathrm{~m}$ fused capillary column $(0.32 \mathrm{~mm})$ packed with RTx-1 (0.1 $\mu \mathrm{m}$ size $)$. The tempera- ture program was the same as in the GC analysis. The carrier gas was helium at flow rate of $1.5 \mathrm{ml} / \mathrm{min}$ and the source voltage was $70 \mathrm{eV}$.

The sterols were identified on the basis of comparison of retention times and mass spectra of the analyzed compounds with authentic standards and literature data.

\section{RESULTS AND DISCUSSION}

Using the weight method, the total amount of sterols was determined, which amounted to $0.2659 \%$. A mixture of sterols' acetates and free sterols were obtained in typical way and next characterized by capillary GC and GC-MS analysis. The occurrence of about 18 sterols has been observed. The structures of 10 of them were identified on the basis of comparison with authentic samples and literature data.

The first eluated peak had an identical RT to cholesteryl acetate. The MS was similar to that obtained for authentic cholesteryl acetate showing molecular ion at $\mathrm{m} / \mathrm{e} 428$, other important ions at m/e $368\left(\mathrm{M}^{+}-\mathrm{H}_{2} \mathrm{O}\right), 353\left[\mathrm{M}^{+}-\right.$ $\left.\left(\mathrm{Me}+\mathrm{H}_{2} \mathrm{O}\right)\right], 247\left[\mathrm{M}^{+}-\left(121+\mathrm{H}_{2} \mathrm{O}\right)\right], 213\left[\mathrm{M}^{+}-\left(\mathrm{sc}+42+\mathrm{H}_{2} \mathrm{O}\right)\right]$ (Smolarz 2000). The MS spectrum of peak 4: 428( $\left(\mathrm{M}^{+}\right)$, $413,368,363,315,288,273,255,229,213$ suggested the presence of cholest-7-en-3 $\beta$-yl acetate.

In the GC/MS analysis of compound 7 and 11 there were visible ions typical for $\Delta^{5}$ sterols fragmentation - ion at $\mathrm{m} / \mathrm{e} 273\left(\mathrm{M}^{+}-\mathrm{sc}\right)$ and ion at m/e $255\left[\mathrm{M}^{+}-\left(\mathrm{sc}+\mathrm{H}_{2} \mathrm{O}\right)\right]$. These ions pointed to the identical structure of constituent 7 and 11 in the steroid part. Additionally the similar scheme of side chain fragmentation was noticeable in compound 7 and 11 through elimination of ions $\mathrm{M}^{+}-\left(\mathrm{H}_{2} \mathrm{O}+67\right)$ and $\mathrm{M}^{+}-$ $\left(\mathrm{H}_{2} \mathrm{O}+93\right)$, respectively for the compound 11 ( $\beta$-sitosterol) ions at $\mathrm{m} / \mathrm{e} 329$ and 303 and for the compound 7 (campesterol) ions at m/e 315 and 289. In the mass spectrum of the compound 8 (stigmasterol) there were visible fragmentized ions at $\mathrm{m} / \mathrm{e} 314,281,271$, which are characteristic for double bond in the side chain (C-22.23) (Nowak and Wolbiś 1998).

TABLE 1. Sterol acetates in inflorescences of Hieracium pilosella.

\begin{tabular}{|c|c|c|c|c|}
\hline Peak & $\begin{array}{c}\mathrm{RT} \\
(\mathrm{min})\end{array}$ & $\begin{array}{c}\mathrm{M}^{+} \\
(\mathrm{m} / \mathrm{c})\end{array}$ & Structural assignment as acetates & Other important ions \\
\hline 1 & 23.35 & 428 & Cholesterol & $368,353,349,326,283,260,247,228,213$ \\
\hline 3 & 23.97 & 426 & Cholesta-5, 7-dien-3 $\alpha$-ol & $366,351,325,311,281,253,227,211$ \\
\hline 4 & 24.18 & 428 & Cholest-7-en-3 $\beta$-ol & $413,368,363,315,288,273,255,229,213$ \\
\hline 5 & - & 442 & Lophenol & $427,382,367,329,269,243,227,173,161,147,119,105,95$ \\
\hline 6 & - & 440 & Ergosta-5, 24-dien-3 $\beta$-ol & $427,396,383,380,365,338,296,282,253,228,227,213$ \\
\hline 7 & 25.08 & 442 & Campesterol & $427,382,367,340,288,274,255,227,213$ \\
\hline 8 & 25.62 & 454 & Stigmasterol & $394,379,351,313,296,282,255,228,213$ \\
\hline 9 & - & - & Unidentified & - \\
\hline 10 & - & - & Unidentified & - \\
\hline 11 & 26.62 & 456 & $\beta$-sitosterol & $396,381,354,327,296,288,275,255,228,213$ \\
\hline 12 & 26.85 & 454 & Fucosterol & $394,379,377,298,296,282,281,253,239,228,213,211$ \\
\hline 13 & 27.23 & 454 & Isofucosterol & $394,379,355,313,296,281,282,253,228,213$ \\
\hline 14 & 27.4 & 456 & $5 \alpha$-stigmast-7-en-3 $\alpha$-ol & $441,396,381,356,315,288,273,255,229,213,201$ \\
\hline 16 & - & 468 & Lanosta-9(11), 24-dien-3 $\beta$-ol? & $453,393,355,255,227,69$ \\
\hline 17 & - & - & Unidentified & - \\
\hline 18 & 28.52 & 468 & 24-ethylidene lophenol & $453,393,370,327,310,267,227$ \\
\hline
\end{tabular}

$\mathrm{RT}$ - retention time

$\mathrm{M}^{+}-$molecular ion 
TABLE 2. Free sterols in inflorescences of Hieracium pilosella.

\begin{tabular}{|c|c|c|c|c|}
\hline Peak & Name of the sterol & $\begin{array}{l}\text { Percent of total fraction } \\
\text { containing sterols' acetates }\end{array}$ & $\begin{array}{l}\text { Percent of total fraction } \\
\text { containing free sterols }\end{array}$ & Percent of $100 \mathrm{~g}$ of plant material \\
\hline 1 & Cholesterol & 24.2 & 21.33 & 0.057 \\
\hline 3 & Cholesta-5.7-dien-3 $\alpha$-ol & 1.22 & - & 0.0029 \\
\hline 4 & Cholest-7-en-3 $\beta$-ol & 3.5 & 7.14 & 0.019 \\
\hline 7 & Campesterol & 6.14 & 5.47 & 0.0145 \\
\hline 8 & Stigmasterol & 6.36 & 6.45 & 0.017 \\
\hline 11 & $\beta$-sitosterol & 41.25 & 42.825 & 0.11 \\
\hline 12 & Fucosterol & 11.38 & 10.405 & 0.028 \\
\hline 13 & Isofucosterol & 0.46 & - & 0.0011 \\
\hline 14 & $5 \alpha$-stigmast-7-en- $3 \alpha-\mathrm{ol}$ & 2.31 & 3.11 & 0.0083 \\
\hline 15 & Stigmasta-7, 24-dien-3 $\beta$-ol & 1.44 & 1.53 & 0.004 \\
\hline 16 & Lanosta-9 (11), 24-dien-3ß-ol? & - & 0.22 & 0.0006 \\
\hline 18 & 24-ethylidene lophenol & 1.435 & 0.68 & 0.0018 \\
\hline
\end{tabular}

Band 12 appeared to be a simple compound with MS showing a molecular ion at $\mathrm{m} / \mathrm{e} 454$ and other important ions at 394, 379, 377, 298, 296, 282, 281, 253, 239, 228, 213,211 , which indicated it to be fucosteryl acetate. The MS fragmentation pattern of compound 14 with a molecular ion at m/e 456 and other important ions at m/e $381\left[\mathrm{M}^{+}-\right.$ $\left.\left(\mathrm{Me}+\mathrm{H}_{2} \mathrm{O}\right)\right], 273\left(\mathrm{M}^{+}-\mathrm{sc}\right), 229\left[\mathrm{M}^{+}-\left(\mathrm{sc}+27+\mathrm{OH}^{-}\right)\right]$indicated the presence of $5 \alpha$-stigmast-7-en-3 $\alpha$-yl acetate (Smolarz 2000).

The probable structures of other 4 sterols were stated on the basis of literature data. There were: lophenol (Masaoud et al. 1995; Nomura et al. 2001), isofucosterol (Debieu et al. 1995; Grandmougin-Ferjani et al. 1999; Largeau et al. 1977; Miller and Gordon 1996; Ponomarenko et al. 1995; Santalova 2004), stigmasta-7.24-dien-3 $\beta$-ol (Brenac and Sauvaire 1996; Cattel et al. 1979; Kintia and Wojciechow- ski 1974; Rohmer et al. 1975), lanosta-9(11), 24-dien-3ß-ol (Ponomarenko et al. 2001), 24-ethylidene lophenol (Rohmer et al.1975) (Table 1).

The GC analysis shows major sterols' mixture composition determined (as acetates) in the inflorescences of Hieracium pilosella: $41.25 \% \beta$-sitosterol, $24.2 \%$ cholesterol, $11.38 \%$ fucosterol, $6.36 \%$ stigmasterol, $6.14 \%$ campesterol, $3.5 \%$ cholest-7-en-3 $\beta$-ol and $2.3 \% 5 \alpha$-stigmast-7-en-3 $\alpha$-ol - of total fraction (Table 2). The sitosterol and cholesterol are remarkably dominating sterols in the analyzed fraction from the inflorescences of $H$. pilosella (Fig. 1).

In the herb and roots from Hieracium pilosella $\beta$-sitosterol is also dominating sterol. However there is no cholesterol in the fractions from herb and roots (Krzaczek et al. 2002). It is quite surprising that cholesterol is the second

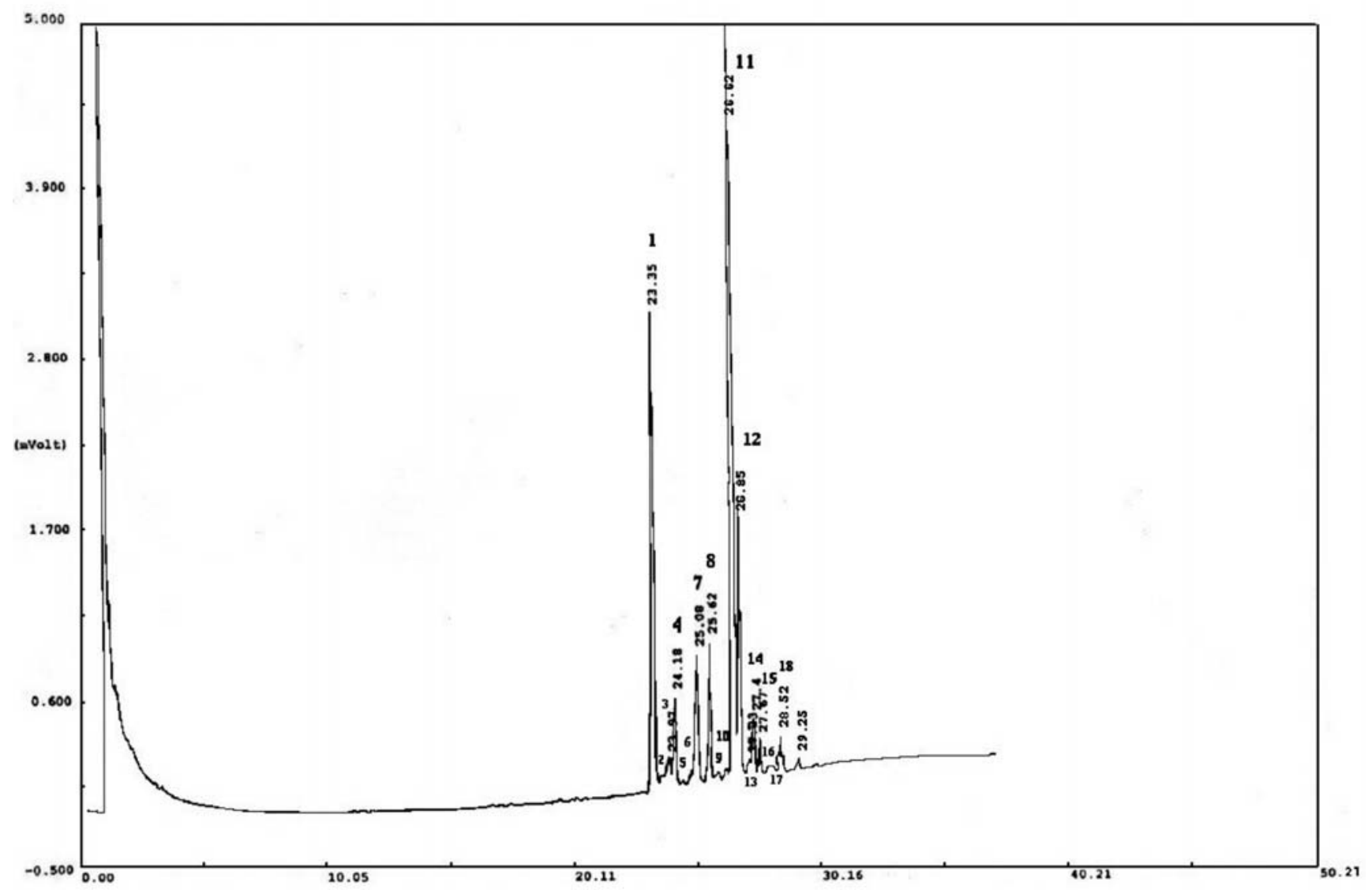

Fig. 1. GC chromatogram of the sterol acetates' mixture from inflorescences of Hieracium pilosella. The numbers of bands are given in Table 1. 
remarkable sterol in the inflorescences of $H$. pilosella. For a long time it was thought that this sterol is characteristic only for the animal kingdom. Nowadays it is known that cholesterol occurs also in plants and is an important link in the sterol synthesis there (Kohlmünzer 1998).

The inflorescences of Hieracium pilosella are the richest in sterols part of the whole plant. In the inflorescences the total amount of sterols is $0.26 \%$, in herb $-0.24 \%$, and in roots $-0.16 \%$ (Krzaczek et al. 2002).

The identified compounds show a certain pharmacological activity and can share the responsibility for the therapeutic features of the examined plant. The major component of the investigated fraction $-\beta$-sitosterol shows antiphlogistic properties and is the main constituent of the medicines used in prostate diseases' treatment and may be used as a supporting remedy in the combined treatment of hypercholesterolemia with the typical drug (some kind of statin) (Kohlmünzer 1998; Richter et al. 1996).

\section{LITERATURE CITED}

BEAUX N., FLEURENTIN J., MORTIER F. 1999. Effect of extracts of Ortosiphon stamineus Benth, Hieracium pilosella L., Sambucus nigra L. and Arctostaphylos uva-ursi (L.) Spreng. In Rats. Phytother. Res. 13: 222-225.

BOWN D. 1999. Wielka encyklopedia ziół. Muza, Warszawa. (in Polish)

BRENAC P., SAUVAIRE Y. 1996. Chemotaxonomic value of sterols and steroidal sapogenins in the genus Trigonella. Biochem. Syst. Ecol. 24: 157-164.

BRODA B., MOWSZOWICZ J. 2000. Przewodnik do oznaczania roślin leczniczych, trujących i użytkowych. PZWL, Warszawa. (in Polish)

CATTEL L., BALLIANO G., CAPUTO O. 1979. Stigmasta-7,E-24(28)-dien-3 $\beta$-ol from Bryonia dioica roots. Phytochemistry 18: 861-862

DEBIEU D., MALOSSE CH., LEROUX P., CORIO-COSTET M.F., STEVA H. 1995. Sterol composition of the vine powdery mildew fungus, Uncinula necator: Comparison of Triadimenol-sensitive and resistant strains. Phytochemistry 39: 293-300 .

DOMBROWICZ E., ŚWIĄTEK L., KOPYCKI W. 1992. Phenolic acids in Inflorescentia Helichrysi and Herba Hieracii pilosellae. Pharmazie 47: 469-470.

GRANDMOUGIN-FERJANI A., DALPÉ Y., HARTMANN M.A., LARUELLE F., SANCHOLLE M. 1999. Sterol distribution in arbuscular mycorrhizal fungi. Phytochemistry 50: 1027-1031.

HARBORNE J.B. 1978. The rare flavone isoetin as a yellow flower pigment in Heywoodiella oligocephala and in other $\mathrm{Ci}$ chorieae. Phytochemistry 17: 915-917.

HEGNAUER R. 1964. Chemotaxonomie der Pflanzen. Bd. 3. Birkhaüser Verlag, Basel and Stuttgart.

HEGNAUER R. 1989. Chemotaxonomie der Pflanzen. Bd. 8. Birkhaüser Verlag, Basel and Stuttgart.
JERZMANOWSKA Z. 1967. Substancje roślinne. Metody wyodrębniania. PWN, Warszawa. (in Polish)

KINTIA P.K., WOJCIECHOWSKI Z.A. 1974. Free and bound sterols in seedlings of Cucumis sativus. Phytochemistry 13: 2235-2238.

KOHLMÜNZER S. 1998, Farmakognozja. PZWL, Warszawa. (in Polish)

KRZACZEK T., ŁUKASIEWICZ E., GAWROŃSKA-GRZYWACZ M. 2002. Sterols in the roots and herb from Hieracium pilosella L. Herba Pol. 48 (4): 206-209.

KUŹNIEWSKI E., AUGUSTYN-PUZIEWICZ J. 1984. Przewodnik ziołolecznictwa ludowego. PWN, Warszawa-Wrocław. (in Polish)

LARGEAU C., GOAD L.J., GOODWIN T.W. 1977. Biosynthesis of sitosterol in barley seedlings. Phytochemistry 16: 1925$-1930$.

MASAOUD M., SCHMIDT J., ADAM G. 1995. Sterols and triterpenoids from Dracaena cinnabari. Phytochemistry 38: 795$-796$.

MILLER L.A.D., GORDON M.H. 1996. Use of lipolysis in the isolation of sterol esters. Food Chem. 56: 55-59.

MOWSZOWICZ J. 1980. Pospolite rośliny naczyniowe Polski. PWN, Warszawa. (in Polish)

NOMURA T., SATO T., BISHOP G.J., KAMIYA Y., TAKATSUTO S., YOKOTA T. 2001. Accumulation of 6-deoxocathasterone and 6-deoxocastasterone in Arabidopsis, pea and tomato is suggestive of common rate-limiting steps in brassinosteroid biosynthesis. Phytochemistry 57: 171-178.

NOWAK S., WOLBIŚ M. 1998. Sterole w niektórych gatunkach rodzaju Scopolia Jacq. Herba Pol. 44 (4): 333-339. (in Polish with English summary)

PONOMARENKO L.P., MAKARIEVA T.N., STONIK V.A., DMITRENOK A.S., DMITRENOK P.S. 1995. Sterol composition of Linneus torquatus (Nemertini) Anopla. Comp. Biochem. Physiol. B, Biochem. Mol. Biol. 111: 575-577.

PONOMARENKO L.P., KALINOVSKY A.I., MOISEENKO O.P., STONIK V.A. 2001. Free sterols from the holothurians Synapta maculata, Cladolabes bifurcates and Cucumaria sp. Comp. Biochem. Physiol. B, Biochem. Mol. Biol. 128: 53-62.

RICHTER W.O., GEISS H.C., SÖNNICHSEN A.C., SCHWANDT P. 1996. Treatment of severe hypercholesterolemia with a combination of beta-sitosterol and lovastatin. Curr. Ther. Res. Clin. Exp. 57: 497-505.

ROHMER M., OURISSON G., BENVENISTE P., BIMPSON T. 1975. Sterol biosynthesis in heterotrophic plant parasites. Phytochemistry 14: 727-730.

SANTALOVA E.A. 2004. Sterols from six marine sponges. Biochem. Syst. Ecol. 32: 153-167.

SMOLARZ H.D. 2000. GC-MS analysis of sterols in Polygonum amphibium L. Chem. Environ. Res. 9 (3 and 4): 259-262.

STONIK V.A., PONOMARENKO L.P., MAKARIEVA T.N., BOGUSLAVSKY V.M. 1998. Free sterol composition from the sea cucumbers. Pseudostichopus trachus, Holothuria nobilis, Holothuria scabra. Comp. Biochem. Physiol. B, Biochem. Mol. Biol. 120: 337-347.

STRZELECKA H., KAMIŃSKA J., KOWALSKI J., WALEWSKA E. 1987. Chemiczne metody badań roślinnych surowców leczniczych. PZWL, Warszawa. (in Polish) 